\section{DIGITAL COMMONS \\ @ UNIVERSITY OF SOUTH FLORIDA}

\section{ABO: Interactive Journal for Women in the Arts, 1640-1830}

Volume 8

Issue 2 Volume 8, Issue 2 Fall 2018

Article 6

2018

\title{
Review of Facing the Text: Extra-IIlustration, Print Culture, and Society in Britain 1769 - 1840 by Lucy Peltz
}

\author{
Madeleine L. Pelling \\ University of York, UK, mp656@york.ac.uk
}

Follow this and additional works at: https://digitalcommons.usf.edu/abo

Part of the Cultural History Commons, History of Art, Architecture, and Archaeology Commons, and the History of Gender Commons

\section{Recommended Citation}

Pelling, Madeleine L. (2018) "Review of Facing the Text: Extra-Illustration, Print Culture, and Society in Britain 1769 - 1840 by Lucy Peltz," ABO: Interactive Journal for Women in the Arts, 1640-1830: Vol.8: Iss.2, Article 6.

https://doi.org/10.5038/2157-7129.8.2.1206

Available at: https://digitalcommons.usf.edu/abo/vol8/iss2/6

This Reviews is brought to you for free and open access by Digital Commons @ University of South Florida. It has been accepted for inclusion in ABO: Interactive Journal for Women in the Arts, 1640-1830 by an authorized administrator of Digital Commons @ University of South Florida. For more information, please contact digitalcommons@usf.edu. 
Review of Facing the Text: Extra-Illustration, Print Culture, and Society in Britain $1769-1840$ by Lucy Peltz

\author{
Abstract \\ Review of 'Facing the Text: Extra-Illustration, Print Culture, and Society in Britian 1769 - 1840,' Lucy Peltz \\ by Madeleine Pelling
}

\title{
Keywords
}

Extra-Illustration, Print Culture, Gender, Book History, Collecting

Creative Commons License

(c) (1) (9)

This work is licensed under a Creative Commons Attribution-Noncommercial 4.0 License 
Lucy Peltz. Facing the Text: Extra-Illustration, Print Culture, and Society in Britain $1769-$ 1840. Huntington Library Press, 2017. xi + 407 pp. 239 illustrations. Index. ISBN:

9780873282611.

Reviewed by Madeleine Pelling

University of York, England

At the end of the eighteenth century, the miniaturist and publisher Robert Bowyer collected seven thousand prints, etchings, and drawings from across Europe, which he collated into a forty-five-volume copy of the Bible. Assembled over three decades, it cost him $£ 3000$, a testament to the value and ambitions represented in such work. So begins Lucy Peltz's Facing the Text. This book provides a comprehensive history of extra-illustration, defined by Peltz as "the process whereby texts, normally in their published state, were customised by the incorporation of thematically linked prints, watercolours, and other visual materials" (1). Peltz, Senior Curator of Eighteenth-Century Portraits and Head of Collection Displays at the National Portrait Gallery, London, organizes the book into three parts, taking her readers deep inside each of its case studies. Beautiful and numerous color illustrations make reading this volume an experience that simulates leafing through the pages of one of the many extraillustrated works discussed by Peltz. The cover of the book sets the tone for the tactility offered alongside rigorous scholarship - three reproductions of eighteenth-century prints have been roughly sliced and pasted onto its cloth boards, lending the book an authentic and immersive feel.

Ranging from 1769 to 1840, the heyday of extra-illustrative practice, Peltz takes us through its social and physical processes. Her review of the vocabulary effective in approaching this sort of enquiry at the start of the book standardizes terms and will be useful to scholars working in the field. The strengths of this study lie in its examination of extra-illustration in relation to gender, sociability, and the cultivation of patriotic and historical narratives. The practice was, for many, a way of signaling antiquarian authority and connoisseurship, contextualized in eighteenth-century concerns with "advocating the glory of Britain past and present" (23). Although this large study deals with the work of both men and women, it is Peltz's attention to extra-illustrated practices applied by women that is most engaging and of special interest to $A B O$ readers.

Part I is titled "Getting Your Heads in Order: Engraved Portrait Collecting and the Origins of Extra-Illustration." Peltz deals principally with the Bull Granger - the extra-illustrated copy of James Granger's Biographical History of England assembled by his friend and contemporary Richard Bull-while tracing the social networks and systems of valuation that shaped both its formation and legacy. In chapter 1, she asserts Horace Walpole as a significant node in Granger's network of print collecting, highlighting his "antiquarian sensibilities and interest in the formation, cataloguing, and transfer of collections between successive owners" (51). Chapter 2 follows the publication of Granger's History and the subsequent epistolary network that developed around the work, as amateur antiquarians wrote to him "in the belief that they were contributing to a communal project whose scope they could both refine and augment" (63). In her exploration of the "social politics" that surrounded the work's reception, Peltz uncovers Granger's aspiration to a "masculine gentility" and cultivation of "the cultural authority of the amateur" (64). Of particular note here is Peltz's discussion of marginalia as a parallel practice to extra-illustration, one that reflects the "symbiosis" between authors and readers that is so central to the latter in what Peltz terms a "performative exchange between the like-minded" (65). In chapter 3, Peltz 
looks more closely at the processes of extra-illustration itself, excavating the Bull Granger to uncover the complex treatment of historical biography. Through sustained analysis of numerous textual and visual sources, Peltz examines the moral, political, and narrative potential of print portraiture in legitimizing historical works and authenticating both collectors and collections. Through surviving correspondence, chapter 4 adds a final node in the Bull Granger coterie-John, Lord Mountstuart, who began "collecting heads" in 1770, meeting Granger three years later. For Peltz, Granger and Bull's interest in Mountstuart's collection of European prints represents important questions about collaborative relationships and authorial discrimination within extra-illustrative circles.

The question of authorship in extra-illustrated works, and the potential within the practice to form new, even competing, dialogues within the same text is developed in Part II, "From Domestic Retirement to a Commercial Marketplace: Amateurs, Antiquaries, and Entrepreneurs." Here, Peltz deals with extra-illustration as a leisured, elite, and usually masculine activity reliant on social networks and private bibliographic exchange. Chapter 1 posits the gentleman's library as the site of this kind of production, providing a brief but useful study of its physical frameworks and cultural significance. The author highlights the prominence of amateur sketches and etchings in collections used for extra-illustration, introducing more focused discussion of gender and class. Peltz's study of the centrality of amateur female artists to extra-illustration networks is important here. Amongst the women she surveys are Georgiana, Duchess of Devonshire and Lady Elizabeth Foster, providing new perspectives on oft-debated figures. However, Peltz stresses that the collecting and assembling of art works produced by women was predominantly carried out by men, raising issues about female agency in economies of patronage and exchange.

In chapters 2 and 3, Peltz shows how print collecting and extra-illustration could not only reflect intimate social bonds and personal associations, but had the potential to interrogate broader issues of patriotism and imperial history. Bull's extra-illustrated copy of William Robertson's The History of America (1778), for example, "dramatized the discovery of the 'New World"' (172). Chapters 4 and 5 look to the work of Thomas Pennant, the antiquarian author whose publications combined topographical surveys with historical tourism. For Pennant, who extra-illustrated his own books, unpublished, or presentation, manuscripts were placed above published texts in a hierarchy of value, evoking a "culture of amateurism" that championed the author's peers and operated away from the market (217). Peltz argues for an "early impetus to extra-illustrate [...] based on a conscious desire to stem the flood of commercially produced materials and enjoy a more rarefied experience of books and images (235). Ironically, Peltz shows us, it was Pennant's popular tour Of London (1790) that "alerted the publishing trade to the commercial possibilities of extra-illustration" (237).

Part III turns to important questions about gender, placing the work of women at the forefront of Peltz's study. Here, she deals more thoroughly with issues of gender, identity, and national heritage, as well as the print market at the end of the eighteenth century. Across 6 chapters, Peltz turns her focus to the Sutherland Clarendon - a multi-volume copy of Edward Hyde, Earl of Clarendon's History of the Rebellion (1702-04) extra-illustrated by Alexander Hendras Sutherland and, later, his widow Charlotte. For Peltz, the Sutherland Clarendon is of historic interest for "its creation in a mature market for historical prints and its transformation - by a woman no less - from a private collection to a work with a claim to national importance" (274). Chapter 1 explores the renewed interest in Clarendon's History at the end of the eighteenth century, positing Sutherland's exquisite work alongside similarly extra-illustrated copies by John Charles Crowle and William Frederick, Duke of Gloucester, who bequeathed his own History to the British Museum in 1834. Using the Sutherland 
Clarendon as its point of entrance, chapter 2 provides a survey of the commercial print market. Despite its somewhat disruptive placement in the section (briefly taking the reader away from what is an otherwise engaging discussion of Charlotte Sutherland's contributions to the work), it details the developments of the print trade, focusing on the relationships between dealers and collectors before painting a colourful picture of the late Georgian auction. Addressing the significant deficit in auction scholarship, Peltz builds on the work of Nigel Ramsay and Cynthia Wall and provides a timely contribution to a growing field of enquiry.

Chapters 3, 4 and 5 take female collecting as their main line of enquiry and form the most exciting and important portion of Peltz's study. The author turns her attention to Charlotte Sutherland's continued efforts to catalogue and augment the assemblage of print portraiture gathered by her husband for use in the Clarendon. Sutherland, Peltz shows, was able to engage with the commercial print market after her husband's demise through cultivation of "the rhetoric of wifely devotion" (273). In her important analysis of Charlotte's Catalogue of the Sutherland Collection, written after twenty years of print collecting, Peltz scrutinizes the text as a model of authorial self-construction and female connoisseurship which allowed for "her bolder and more assertive identity" as an experienced collector (332).

The opportunities and limitations of gender are scrutinised here, with Peltz unpacking Charlotte's Sutherland's efforts in the wider context of female collecting and domestic craft. Peltz's focus on "collecting as women's work" is an important addition to scholarly conversations about gender and material culture led by scholars such as Amanda Vickery, Elizabeth Eger, and Beth Fowkes Tobin, although it does make up a relatively small section in an otherwise comprehensive volume. Peltz surveys several other women collectors, including Catherine the Great, Queen Charlotte, and the Duchess of Portland, highlighting the common narrative of performativity that unites their collecting legacies: "They were distinguished not just by size of purse but also for holding positions at court predicated on conspicuous consumption" (309). "Further down the social spectrum," Peltz notes, "women who collected art tended to elicit little more than scorn" (309). While she has contributed significantly to discussions of gender and print culture, publishing widely on the subject and co-curating the exhibition Brilliant Women: $18^{\text {th }}$-Century Bluestockings (2008), Peltz gives relatively little space and interrogation to these deserving histories. Instead, staying with Charlotte Sutherland, Peltz asserts the necessity of recovering women's antiquarian labor, paving the way for future scholarship. A well-conceived chapter 6 concludes Peltz's study, surveying the cultural and scholarly legacies of extra-illustration through the nineteenth century, identifying the moment the Sutherland Clarendon was gifted to the Bodleian Library in 1837 as a turning point in the history of extra-illustration, coinciding with "the inexorable rise of museums and libraries as repositories of history, the faltering print market, and the decline of extra-illustration as a popular practice" (347).

In prioritizing a number of perspectives, Peltz invites her readers to think rigorously about the various modes of engagement with print culture in the eighteenth and early nineteenth centuries. She demonstrates the development of extra-illustration across amateur and commercial circles, focusing on questions of authorship, gender, and sociability and positioning the extra-illustrator as occupying "a hybrid status in relation to such customized literary artifacts" (213). Peltz's book manages to advance the field of material and print culture studies considerably and will appeal primarily to art historians, as well as those working on the history of collecting and book history. 